\title{
FENOMENA PENIMBUNAN BBM BERSUBSIDI \\ DI KOTA PEKANBARU
}

\author{
Fauzan Nur Dan Sobri
}

\begin{abstract}
In the years 2013 to 20014, revealed there were 72 cases of hoarding subsidized fuel in Pekanbaru. In a number of very pantastis to measure the extent of the area of Pekanbaru. At least there are several indications supporting the presence of the phenomenon of hoarding subsidized fuel in Pekanbaru include: factors opportunities, linking between the demand by business operators on the one hand, easy to obtain fuel at the pump through unscrupulous employees with mode-specific mode on the other hand, as well as the role of local police officers as security at a time furnisher. The next factor is the lack of oversight by the government and authorities in the field and lack of legal sanctions in providing a deterrent effect for offenders caught.
\end{abstract}

Key words: Blue Collar Crime

\begin{abstract}
ABSTRAK
Dalam tahun 2013 hingga 20014, terungkap ada 72 kasus penimbunan BBM bersubsidi di Pekanbaru. Secara jumlah sangat pantastis untuk ukuran wilayah sebatas Kota Pekanbaru. Setidaknya terdapat beberapa indikasi pendukung hadirnya fenomena penimbunan BBM bersubsidi di Pekanbaru diantaranya : faktor peluang, yang mengkaitkan antara permintaan oleh pelaku usaha disatu sisi, mudahnya mendapatkan BBM di SPBU melalui oknum pegawainya dengan modus-modus tertentu disisi lain, serta peran oknum aparat sebagai pengaman sekaligus pemberi informasi. Faktor berikutnya adalah lemahnya pengawasan oleh pemerintah dan aparat berwenang di lapangan serta rendahnya sanksi hukum dalam memberikan efek jera bagi pelaku yang tertangkap.
\end{abstract}

Kata Kunci :Blue Collar Crime

\section{PENDAHULUAN}

Indonesia adalah salah satu Negara di dunia yang menerapkan kebijakan subsidi Bahan Bakar Minyak (BBM) untuk membantu masyarakat ke bawah di Indonesia, mengingat BBM adalah salah satu kebutuhan mendasar bagi masyarakat modern saat ini. Subsidi BBM dari pemerintah mencapai hampir 50\% (lima puluh persen) pengurangan harga dari harga jual BBM dasar. Dapat dibandingkan

BBM Jenis solar misalnya, harga subsidi Rp 5.500,00 sementara non-subsidi Rp 10.200,00. Begitu juga untuk harga Premium.

Namun sayangnya niat baik
pemerintah tersebut tidak serta merta
berdampak positif kepada masyarakat dalam
pengertian, capaian sasaran yang sejatinya

diperuntukan khusus terhadap masyarakat ekonomi lemah, menjadi meluas termanfaatkan juga bagi masyarakat ekonomi kelas atas. Hal itu mudah difahami dari kenyataan bahwa seluruh masyarakat yang terbilang mampu dilihat dari kepemilikan kendaraan dengan jenis mobil, secara bebas juga dapat menggunakan BBM bersudsidi tersebut. Alhasil, jumlah anggaran yang besar (Puluhan Trilyunan Rupiah) dikucurkan oleh pemerintah guna menutupi setengah dari harga BBM dari harga dasarnya tersebut, dapat dikatakan hanya menguntungkan masyarakat kelas menengah ke atas belaka. Hal ini dikarenakan kebutuhan BBM kelas menegah ke atas dengan kepemilikan kendaraan jenis roda empat (mobil) lebih membutuhkan banyak BBM ketimbang masyarakat kelas bawah yang 
notabene hanya menggunakan kendaraan roda dua (sepeda motor) dan sebagainya.

Nah, disamping persoalan di atas, dalam proses distribusi BBM bersubsidi dilapangan, ternyata banyak pula mengalami masalah-masalah lain. Diantaranya dimanfaatkannya BBM bersubsidi tersebut oleh segelintir orang untuk mendapatkan keuntungan dengan cara melakukan praktek penimbunan untuk dijual dengan nilai relatif di bawah harga industri dengan sasaran penjualan industri atau pelaku usaha rekanan. Konsekuensi dari fenomena ini tak jarang berdampak kepada langkanya BBM bersubsidi ditengah-tengah masyarakat. Tindakan penimbunan BBM bersubsidi untuk dijual dengan harga industri adalah jelas sebagai kejahatan yang tidak hanya merugikan ekonomi Negara, terlebih lagi perampasan Hak Asasi Manusia terhadap masyarakat miskin penerima subsidi.

Masalah penimbunan BBM bersubsidi di wilayah Kota Pekanbaru bukanlah masalah baru yang dalam perjalanannya membuat

\section{PEMBAHASAN}

Penimbun BBM Bersubsidi di Pekanbaru Identik Sebagai Realitas "Blue Collar Crime".

Sebagai kejahatan yang merugikan Negara dan Masyarakat Kota Pekanbaru, pelaku penimbun BBM bersubsidi secara umum lebih mencirikan model atau modus pola konvensional (Blue Collar Crime ${ }^{16}$ ) ketimbang penimbun kelas atas (White Collar Crime $^{17}$ ). Jika penimbun BBM

\footnotetext{
16. Blue Collar Crimeadalah sebuah konsep kebalikan dari White Collar Crime, lebih mengarah pada jenis kejahatan kelas bawah. (www:/http. Study.com)

17. Kajian white collar crime sendiri mulai dipopulerkan oleh Edwin H. Sutherland pada tahun
}

jajaran Institusi Kepolisian Daerah Riau mengalami kesulitan dalam upaya pemberantasannya hingga titik Nol. Dapat dibayangkan sepanjang tahun 2013 hingga 2014 di Pekanbaru ditemukan 72 kasus penimbunan bahan bakar minyak solar bersubsi yang terungkap oleh Dit Reskrimsus Polda Riau. Antara lain sebanyak 60 kasus di tahun 2013 dan 12 kasus di tahun 2014.

Hasil penyelidikan pihak Kepolisian ditemukan berbagai modus operasi yang dilakukan oleh pelaku kejahatan penimbunan BBM solar bersubsidi ini. Namun secara umum modus yang digunakan pelaku penimbunan BBM dengan cara memodifikasi tangki minyak mobil seperti mobil Mitsubitshi L300 diganti dengan tangki truk Fuso yang berkapasitas mencapai 300-500 liter. Dapat diperkirakan berapa banyak BBM akan terkumpul oleh pelaku sekiranya ia melakukan pengisian beberapa kali dalam tiap harinya di tiap-tiap Pomp BBM yang ada di Kota Pekanbaru ini.

yang terungkap dari hasil investigasi aparat Kepolisian seperti di Pekanbaru dimana pelaku lebih memanfaatkan akumulasi pembelian melalui Pompa bensin yang ada di sekitar Kota Pekanbaru, maka penimbun ala kelas atas (White Collar Crime), cenderung menggunakan instrumen kekuasaan ntah sebagai penyalur (distributor) resmi yang mengantongi izin dan sebagainya namun dalam pelaksanaannya BBM

1939, saat berbicara di depan pertemuan tahunan American Sociological Society ke-34 di Philadelphia tanggal 27 Desember, yang dia istilahkan sebagai perbuatan kejahatan oleh orang yang terhormat dan memiliki status tinggi serta berhubungan dengan pekerjaannya.( Gary S. Green. 1990. Occupational Crime. Chicago: Nelson-Hall. Hal 7). 
tersebut diselewengkan sebagian atau seluruhnya untuk tidak didistribusikan.

Selain modus dan cara kerja berbeda, dari sisi jumlah serta potensi tersentuh oleh jangkauan aparat hukum juga jauh berbeda. Jika penimbun konvensional hanya dapat mengakumulasi seadanya dengan sebaran distribusi lebih kecil. Disisi lain pelaku

Faktor-Faktor Melatarbelakangi Pelaku Penimbun BBM Bersubsidi di Pekanbaru

Berdasarkan temuan informasi dilapangan, tergambarkan bahwa ada bayak faktor yang melatarbelakangi terjadinya praktek kejahatan penimbunan BBM bersubsidi di Kota Pekanbaru antara lain :

1. Peluang

Peluang yang dimaksud dalam masalah ini adalah : Pertama keamanan dari oknum aparat baik oknum TNI maupun oknum Polri sebagai beking terhadap dilakukannya kejahatan penimbunan BBM Bersubsidi tersebut. Kedua terbukanya peluang kerja sama terhadap oknum petugas penjualan BBM di Stasiun Pengisian Bahan Bakar Umum (SPBU) tempat pelaku membeli BBM.

Dalam melakukan praktek penimbunan BBM bersubsidi pelaku "dibeking” oleh oknum TNI dan Polisi, kerjasama antara pelaku dan

oknum penegak hukum ini merupakan suatu bentuk hubungan yang saling menguntungkan bagi kedua pihak (simbiosis mutualism). Selain alasan keamanan, melalui oknum penegak hukum tersebut pelaku kejahatan mendapatkan imformasi lengkap tentang momen waktu yang tepat untuk melakukan aksi pembelian dan lokasi penimbunan yang dimungkinkan lepas dari perhatian pihak berwenang. konvensional juga mudah teridentifikasi aparat dikarenakan cara kerjanya yang tampak atau terduga (kasat mata). sedangkan penimbun kelas atas dapat mengakumulasi dalam skala jauh lebih besar dengan sebaran distribusi cukup luas serta nyaris tersentuh aparat karena sifatnya yang terselubung dibalik administrasi resmi (tak kasat mata).

Selain itu pula, imformasi dari oknumoknum dimaksud bebih dahulu sampai ke pelaku di lapangan jika ada operasi pemeriksaan di setiap tempat-tempat yang diduga sebagai tempat penimbunan. Sehingga pelaku kejahatan punya kesempatan untuk menghilangkan barang bukti yang dapat membongkar kejahatan yang mereka lakukan.

Sedangkan bekerjasama dengan oknum operator Stasiun Pengisian Bahan Bakar Umum (SPBU) memberi kemudahan bagi pelaku kejahatan peminimbunan BBM ketika membeli dengan jumlah banyak dan berulangulang di SPBU tersebut. Hubungan kerja sama ini selain mendapat kemudahan dalam membeli dengan jumlah banyak dan berulang-ulang, pelaku kejahatan penimbunan bisa melakukan aksinya tanpa dicurigai oleh orang lain, dengan cara berbagi imformasi jadwal tugas oknum operator SPBU ketika akan melakukan aksi pembelian.

\section{Lemahnya Kontrol}

Bentuk penimbunan BBM bersubsidi di Kota Pekanbaru tidak lepas juga dari lemahnya pengawasan (kontrol) oleh pihak terkait baik pihak Pemerintah Kota Pekanbaru maupun aparat hukum. Hal ini ditandai dengan jarangnya investigasi ke lapangan ke tempattempat yang patut di duga melakukan praktik penimbunan baik oleh Pemerintah maupun 
aparat hukum. Selain itu pengawasan terhadap Stasiun Pengisian Bahan Bakar Umum (SPBU) juga nyata tidak dilakukan. Hal ini sebenarnya sangat penting dan utama, mengingat sumber minyak bagi pelaku penimbunan di Pekanbaru berasal dari SPBU yang ada, melalu cara pembelian dengan memanipulasi tangki mobil dengan kapasitas tengki yang lebih besar dan dilakukan berulang-ulang.

\section{Keuntungan Tinggi dengan Resiko Hukum Kecil}

Bagi pelaku kejahatan yang berorientasi ekonomi, pertimbangan pertama tentu akan selalu merasionalisasikan antara keuntungan tindak kejahatan yang

dilakukan dengan potensi resiko yang mungkin dihadapi. Demikian pula dengan pelaku kejahatan penimbunan BBM bersubsidi wilayah Kota Pekanbaru. Keuntungan dalam kejahatan ini terbilang cukup tinggi mengingat selisih harga beli BBM bersubsidi dengan harga nonsubsidi sebagaimana daftar harga BBM bersubsidi jenis Solar saat pendalaman informasi ini dilakukan : bersubsidi Rp 5.500,00 - Non Subsidi Rp 10.200,00.

Dilihat dari selisih harga sebagaimana di atas, keuntungan yang diperoleh bagi pelaku penimbun BBM bersubsidi hampir mencapai $100 \%$ dari nilai modal pembelian di SPBU. Besarnya selisih antara pembelian dan penjualan mereka di lapangan inilah yang memungkinkan bagi mereka yang terlibat (pelaku dan para oknum baik aparat maupun petugas SPBU) bersengkokol bersama dimana di dalamnya sudah terdapat pembagian kerja.

Secara sederhana dapat digambarkan, untuk mendapatkan satu truk tangki kapasitas 5000 liter, tidak harus membutuhkan waktu
Dalam konteks di atas, pengawasan dengan menempatkan petugas diikuti dengan pendekatan "pengetatan aturan dan sanksi nyata" bagi pihak manajemen SPBU yang menjual BBM di luar pemakaian yang "wajar" seharusnya menjadi penting dan wajib dilakukan oleh Pemerintah Kota Pekanbaru.

lama dengan katakanlah 2 unit mobil Mitsubitshi L300 yang telah didesain tangkinya khusus membeli BBM di Pompa Bensin di wilayah Kota Pekanbaru dengan kapasitas tangki 300-500 liter/sekali isi. Nah dari perhitungan itu, dalam seminggu dapat diduga para penimbun minimal mendapatkan 2 truk kapasitas 5000 liter yang siap untuk di jual ke pembeli (pihak industri luar daerah) yang memang sudah bekerja sama pula dengan harga relative di bawah harga industri. Namun dapat dipastikan jauh di atas harga pasaran subsidi pada SPBU.

Asumsi minimal 10.000 liter/minggu seperti di atas, jika di hargakan dengan penjualan mereka katakanlah Rp. 9.500,00,/liter saja, maka sudah selisih Rp. 4.000,00.dari selisih harga pembelian di SPBU. Dengan demikian dengan perhitungan minimal Rp. 40.000.000,00.- keuntungan dalam seminggu, mereka dapatkan dari kejahatan ini. Dengan begitu, sangat beralasan bagi mereka untuk bersengkongkol melibatkan berbagai pihak tersebut dengan pembagian penghasilan yang lebih menggiurkan dibanding pendapatn/gaji formal ditempat mereka bekerja dalam setiap bulannya.

Problem lain yang membuat konplotan pelaku kurang sedikit takut melakukan aksi 
kejahatan ini hingga terus ada di Pekanbaru, tidak dapat dipisahkan dengan rendahnya sangsi hukum. Dari beberapa catatan merujuk hasilhasil keputusan hukuman yang diterima seorang pelaku kejahatan penimbunan bahan bakar minyak solar bersubsidi sangat rendah. Terkait dengan rendahnya hukuman bagi pelaku kejahatan penimbun BBM Bersubsidi di kota pekanbaru, menurut Robby Prasetya Tindra Putra, SH.,MH (Jaksa di Kejaksaan Negeri Pekanbaru) dan Pakar Hukum Dr.Firdaus, MH, memberikan tanggapan yang relatif sama. Mereka menggarisbawahi, "hukuman yang diterima oleh pelaku penimbun Bahan Bakar Minyak Solar Bersubsidi, dikenakan sanksi hukum mengacu Pasal 55 Undang-Undang RI

\section{PENUTUP}

Dari uraian yang telah disampaikan, dapat dimengerti bahwa fenomena penimbunan BBM bersubsidi jelas merupakan berorientasi ekonomi. Meskipun secara tipologi modus yang digunakan identik dengan pola-pola Blue Collar Crime yang notabene pemain kelas bawah, akan tetapi jika tidak dihentikan dan senantiasa terus saja berlangsung, maka dapat dipastikan secara jumlah BBM bersubsidi yang mereka curi dapat melampaui jumlah yang dilakukan oleh pelaku penimbun kelas atas (White Collar Crime) yang lebih licik itu.

Dampak dari pencurian BBM bersubsidi ini sudah barang tentu tidak hanya merugikan keuangan Negara, namun lebih parah lagi merupakan perampasan "Hak Dasar" masyarakat kelas bawah. Meski masyarakat umum kelas bawah belum tentu merasakan hal itu karena tidak bersifat langsung, akan tetapi dampaknya ke masyarakat juga.
Nomor 22 Tahun 2001 Tentang Minyak dan Gas Bumi Jo Pasal 55 Ayat (1) ke 1 KUHP. Sementara penjelasan mereka menerangkan jika pasal 55 tidak mengatur tentang ancaman pidana minimal, dan Pasal tersebut hanya mengatur ancaman pidana Maksimal 6 tahun kurungan penjara dan didenda $R p$. 60.000.000.000,00 (enam puluh miliar rupiah). Apabila terdakwa tidak sanggup membayar denda tersebut maka terdakwa menggantinya dengan kurungan penjara. Untuk itu biasanya Jaksa Penuntut Umum berhubungan dengan pasal 55 melihat jumlah barang bukti yang ada dan berapa besarnya Negara dirugikan oleh tindakan kejahatan yang dilakukan oleh terdakwa".

Untuk itu pemerintah (Pusat dan Daerah) tidaklagi boleh diam menyikapi persoalan besar ini. Harus ada pemecahan masalah yang mendasar perlu dilakukan setidaknya menyangkut :

1. Pemerintah wajib pastikan agar konsumen SPBU tidak dapat membeli BBM diluar jumlah kewajaran. Sekaligus perlu didesain sistem jaringan yang terintegrasi bagi tiaptiap SPBU yang dapat mengidentifikasi pengisian yang berulang-ulang (kendaraan jenis mobil) dalam rentang satu waktu

2. Pemerintah wajib pastikan untuk setiap industri mendapatkan BBM dengan standart harga industri. Konsekuensi sanksi tegas harus diprioritaskan untuk persoalan ini. Bagaimanapun industri (pelaku usaha) juga sebagai pelaku kejahatan ${ }^{18}$ manakala

\footnotetext{
18. Corporate crime, menurut Kramer (1984) adalah kejahatan yang dilakukan oleh organisasi korporat. Hal ini adalah hasil dari kebijakan yang diambil oleh para petinggi perusahaan. Dan perusahaan membuat
} 
memanfaatkan BBM bersubsidi dalam

kegiatan usahanya.

3. Pemerintah Pusat dan DPR-RI harus merefleksi ulang untuk revisi terkait Undang-Undang RI Nomor 22 Tahun 2001 Tentang Minyak dan Gas Bumi, yang notabene secara sanksi masih jauh semangatnya dalam konteks memberikan efek jera.

\section{SUMBER REFRENSI}

\section{Buku :}

E. Hochstedler (ed.). Corporations as Criminals. Beverly Hills, CA: Sage

Gary S. Green. 1990. Occupational Crime. Chicago: Nelson-Hall

\section{Undang-Undang :}

Undang - Undang Republik Indonesia Nomor 22 Tahun 2001 Tentang Minyak dan Gas Bumi.

keputusan tersebut untuk memperoleh keuntungan untuk perusahaan

Dalam E. Hochstedler (ed.). Corporations as Criminals. Beverly Hills, CA: Sage. Hal 13-38. 